\title{
Evaluation of Impact of Graves Disease on some Selected Haematological Markers among Subjects in Enugu, Nigeria
}

\author{
Obeagu EI ${ }^{1}$, Azuonwu $\mathrm{O}^{2 *}$, Didia $\mathrm{BC}^{3}$ and Obeagu $\mathrm{GU}^{4}$ \\ ${ }^{1}$ Department of Health Services, Michael Okpara University of Agriculture, Nigeria \\ ${ }^{2}$ Department of Medical Laboratory Science, Rivers State University, Rivers State, Nigeria \\ ${ }^{3}$ Department of Medicine and Surgery, Rivers State University, Rivers State, Nigeria \\ ${ }^{4}$ Department of Nursing Science, Ebonyi State University, Abakaliki, Nigeria
}

Submission: October 05, 2017; Published: October 31, 2017

*Corresponding author: Azuonwu 0, Department of Medical Laboratory Science, Rivers State University, Port Harcourt, Nigeria, Africa, Email: bimajacobs@yahoo.co.uk

\begin{abstract}
Introduction: Graves disease is an autoimmune disease that rarely occurs with its excruciating pains especially when described as toxic goiter with increased levels of thyroid hormones leading to high metabolic rates. It occurs more in developing Countries than in developed. The study was done to evaluate the impact of Graves' disease on some selected hematological markers.

Method: The study was done in a secondary health institution in Enugu, Nigeria. A total of fifty two (52) subjects were recruited for the study, 12 (8, females, 4 males) were Graves disease subjects aged 40 -67 years, 40 (20 females, 20 males) were apparently healthy individuals (control) age matched to the patients. The study was done from January 2015- March 2017. A $2 \mathrm{ml}$ of venous blood was collected from each participant and placed into EDTA container for hematological assay using Mindray BC-5300.
\end{abstract}

Observation: The results show significant increase $(\mathrm{P}<0.05)$ in total white blood cell, Neutrophil, Monocyte, Mean cell haemoglobin concentration and Erythrocyte sedimentation rate of the Graves' disease subjects $(17.3 \pm 2.6 \mathrm{X} 109 / \mathrm{L}, 88.8 \pm 12.0 \%, 3.7 \pm 0.3 \%, 365.0 \pm 21.0 \mathrm{~g} / \mathrm{l}$, $112.0 \pm 6.7 \mathrm{~mm} / \mathrm{hr}$ ) compared to the control $(5.2 \pm 1.5 \mathrm{X} 109 / \mathrm{L}, 68.1 \pm 8.3 \%, 1.0 \pm 0.1 \%, 336.0 \pm 15.2 \mathrm{~g} / \mathrm{l}, 8.9 \pm 3.2 \mathrm{~mm} / \mathrm{hr}$, significant decrease $(\mathrm{P}<0.05)$ in Lymphocyte, red blood cell, Haemoglobin, packed cell volume, mean cell volume and platelets $(7.2 \pm 0.5 \%, 3.0 \pm 0.4 \mathrm{X} 1012 / \mathrm{L}$, $7.8 \pm 0.6 \mathrm{~g} / \mathrm{dl}, 21.3 \pm 3.5 \%, 71.4 \pm 8.4 \mathrm{fl}, 150.0 \pm 13.1 \mathrm{X} 109 / \mathrm{L})$ compared to the control $(30.7 \pm 5.2 \%, 5.1 \pm 0.7 \mathrm{X} 1012 / \mathrm{L}, 13.7 \pm 1.2 \mathrm{~g} / \mathrm{l})$ and no significant difference $(\mathrm{P}>0.05)$ in eosinophil, basophil and mean cell haemolgobin of the Grave's disease subjects compared to the control.

Conclusion: Graves disease has a serious impact in hematological markers of the patients which could be because of effect of increased thyroid hormone synthesis. This calls for serious attention in the management of the patients especially when they present to the hospital.

Keywords: Graves' disease; hematological markers; Enugu; Public health

Abbreviations: ESR: Erythrocyte Sedimentation Rate; WBC: Total White Cell Count; RBC: Red Blood Cell; PCV: Packed Cell Volume; MCV: Mean Cell Volume; MCH: Mean Cell Haemoglobin; MCHC: Mean Cell Haemoglobin Concentration; GD: Graves' Disease Subjects

\section{Introduction}

Graves' disease also known as toxic goiter is an autoimmune disease that affects the thyroid [1] and frequently results to hyperthyroidism and most times promotes the enlargement of thyroid gland. Nonetheless, it is strongly reported that about 25 to $80 \%$ of people with the condition develop eye defects with its associated clinical problems over time [2]. The specific cause is confusing and complicated per se; but, it is strongly reported and established by some researchers to involve a combination of genetic and environmental factors [1]. The early manifestation of the disease may be triggered by stress, infection, and pregnancy [2]. The risk of the disease may be increased with smoking and may worsen eye problems.

The disease results from an immunoglobulin, called thyroid stimulating immunoglobulin (TSI), that has the same function to thyroid stimulating hormone (TSH) and TSI antibodies cause the thyroid gland to synthesize increased thyroid hormone over time [2]. Graves' disease will develop in about $0.5 \%$ of males 
and $3 \%$ of females. It occurs about 7.5 times more often in women than in men based on the complicated risk factors that made women more vulnerable and susceptible to the clinical condition. Nonetheless, it starts between the ages of 40 and 60, but can begin at any age [3]. The signs and symptoms of Graves' disease virtually all result from the direct and indirect effects of hyper thyroidism [4].

Graves' disease is an autoimmune disorder, in which the body produces antibodies to the receptor for thyroidstimulating hormone. These antibodies cause hyperthyroidism because they bind to the TSHr and chronically stimulate it. The TSH $r$ is expressed on the follicular cells of the thyroid gland, and the result of chronic stimulation is an abnormally high production of T3 and T4. This, in turn, causes the clinical symptoms of hyperthyroidism, and the enlargement of the thyroid gland visible as goiter [4]. However, it is firmly reported that if left untreated, more serious clinical complications could result, including birth defects in pregnancy, increased risk of a miscarriage, bone mineral loss and in extreme cases, death. Graves' disease is often accompanied by an increase in heart rate, which may lead to further heart complications [5].

The total red blood cell mass is increased [6-8] even though the survival time of erythrocytes is shortened, at least in some patients $[9,10]$. Total blood volume is also related to the oxygen requirement as expressed by the basal metabolic rate, and is elevated in hyperthyroidism. The observation that indices such as haematocrit, haemoglobin and red cell count are not elevated in hyperthyroidism despite an increase in total red cell mass has been attributed to this concomitant increase in plasma volume [11]. It is strongly believed that the important of this study cannot be underscored especially, in this part of the world where there is an increasing trend of paucity of data and general clinical health education on the above subject matter. It is firmly believed that data generated from this study would be useful in the treatment, management and prompt diagnosis of the clinical outcome to improve the health condition of the patients. Furthermore, the collective aim of the study was to evaluate the clinical impact of Graves' disease on some selected hematological markers in Enugu, Nigeria.

\section{Materials and Methods}

\section{Study area}

The study was done in Niger Foundation Hospital, Independence Layout, Enugu, Nigeria.

\section{Study design}

The study is a hospital based case study using purposive sampling technique.

\section{Subjects}

The subjects comprised of a total of fifty two (52) subjects, 12 subjects were patients aged 40-67 years diagnosed with Graves' disease( 8 females and 4 males) and 40 (20 females, 20 males) subjects were apparently healthy individuals aged matched as the control.

\section{Haematological investigation}

The hematological investigations were done using Mindray BC-5300.The parameters investigated include total white cell, Neutrophil, Lymphocyte, Monocyte, Eosinphil, Basophil, red blood cell, haemoglobin, packed cell volume, mean cell haemoglobin, mean cell haemoglobin concentration, platelets, and erythrocyte sedimentation rate.

\section{Ethical consideration}

Ethical approval was gotten from the relevant health agencies that are directly involved to grant approval, also informed consents were obtained before sample collection from the subjects and the confidentiality of the results ensured throughout the period of study till date.

\section{Statistical analysis}

The results were presented in tables as mean and standard deviation and student t-test used for analysis and the level of significance was set at $\mathrm{P}<0.05$

\section{Results}

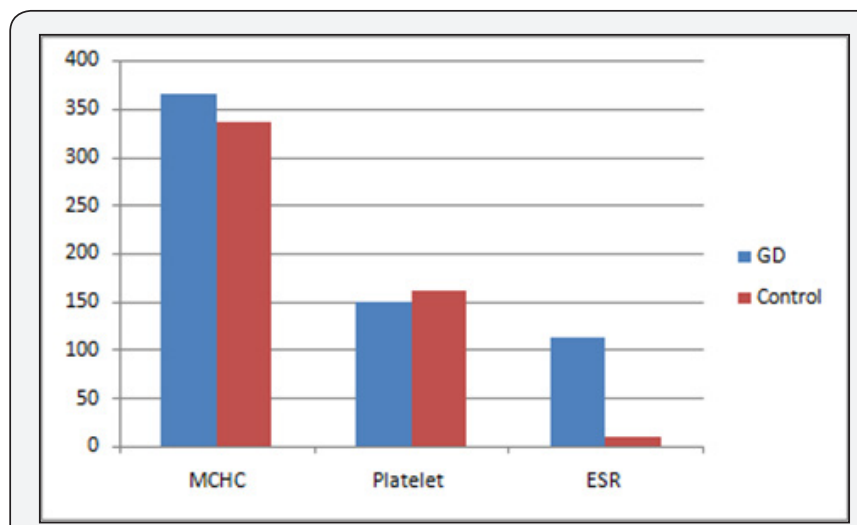

Figure 1: Showing MCHC, Platelets, ESR of the subjects. $\mathrm{GD}=$ Graves' disease subjects

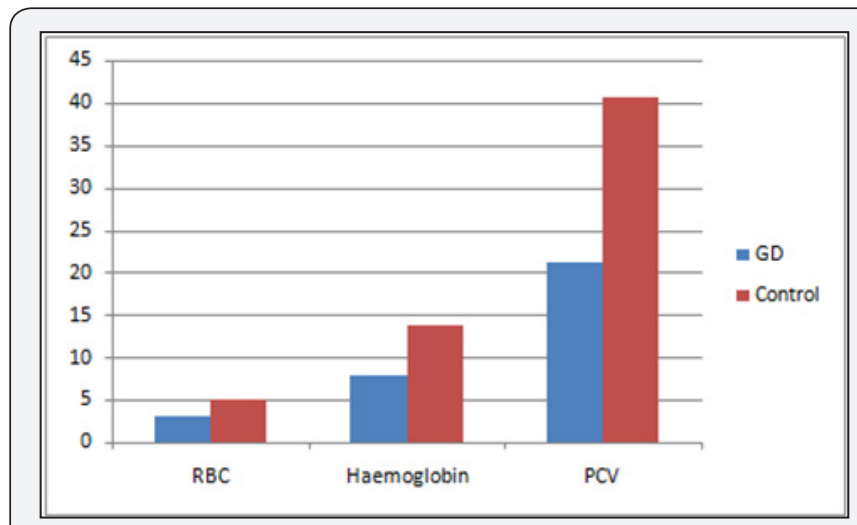

Figure 2 : Showing RBC, Haemoglobin and PCV of the subjects. $\mathrm{GD}=$ Graves' disease subjects 


\section{Open Access Blood Research \& Transfusion Journal}

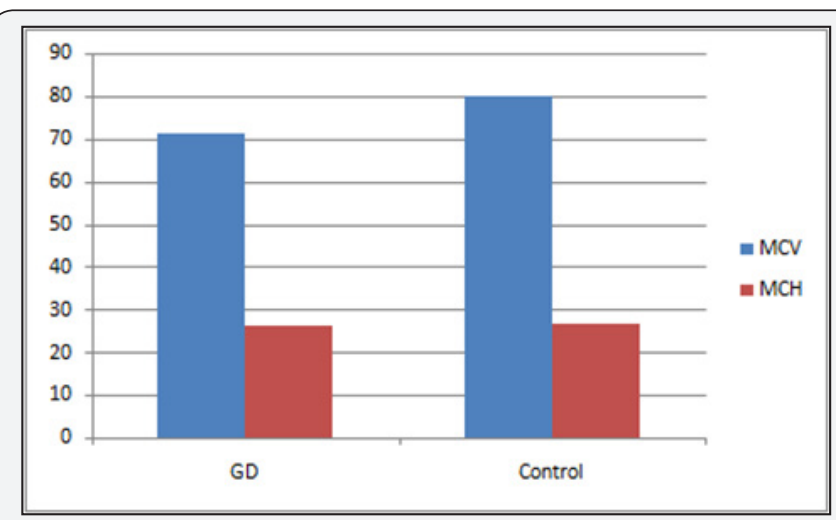

Figure 3 : Showing MCV and MCH of the subjects.

$\mathrm{GD}=$ Graves' disease subjects

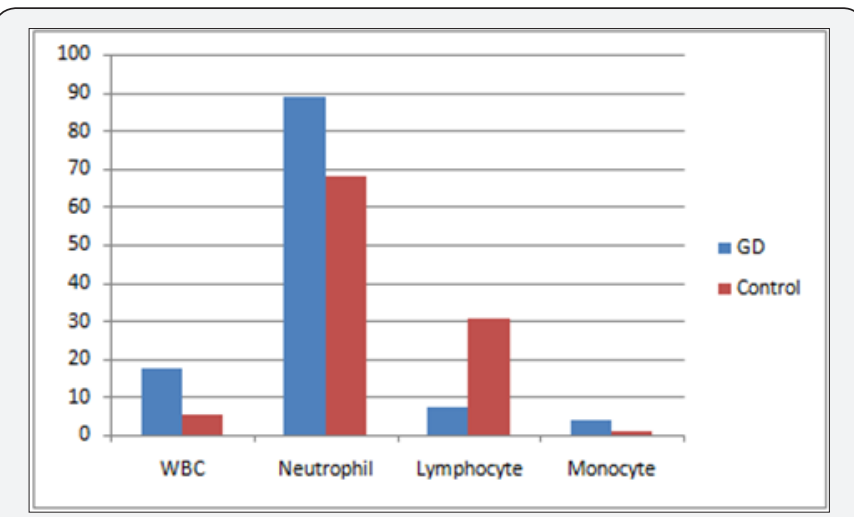

Figure 4 : showing WBC, Neutrophil, Lymphocyte, Monocyte of the subjects.

$\mathrm{GD}=$ Graves' disease subjects

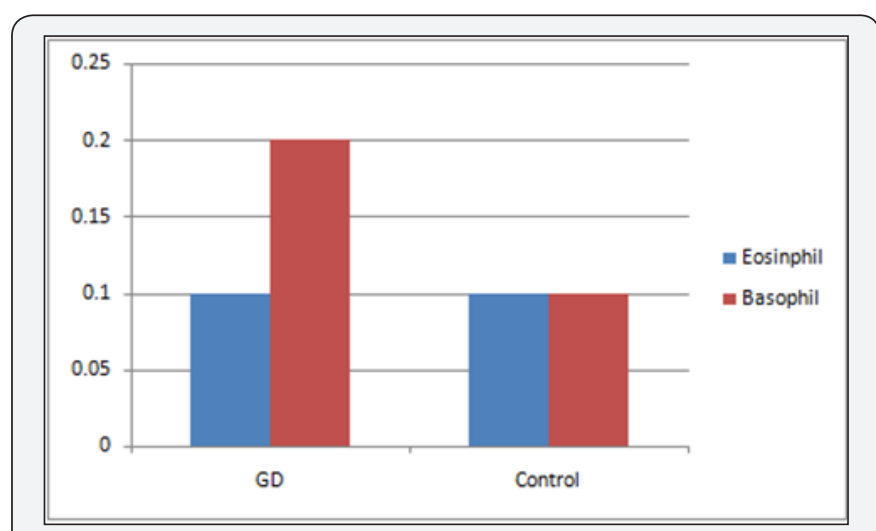

Figure 5 : Showing eosinophil and basophil of the subjects.

$\mathrm{GD}=$ Graves' disease subjects

The results show a significant increase $(\mathrm{P}<0.05)$ in Total white blood cell, Neutrophil, Monocyte, Mean cell haemoglobin concentration and Erythrocyte sedimentation rate of the Graves' disease subjects $\left(17.3 \pm 2.6 \mathrm{X} 10^{9} / \mathrm{L}, \quad 88.8 \pm 12.0 \%\right.$, $3.7 \pm 0.3 \%, 365.0 \pm 21.0 \mathrm{~g} / \mathrm{l}, 112.0 \pm 6.7 \mathrm{~mm} / \mathrm{hr}$ ) compared to the control $\left(5.2 \pm 1.5 \times 10^{9} / \mathrm{L}, 68.1 \pm 8.3 \%, 1.0 \pm 0.1 \%, 336.0 \pm 15.2 \mathrm{~g} / \mathrm{l}\right.$, $8.9 \pm 3.2 \mathrm{~mm} / \mathrm{hr}$, significant decrease $(\mathrm{P}<0.05)$ in Lymphocyte, red blood cell, Haemoglobin, packed cell volume, mean cell volume and platelets $\left(7.2 \pm 0.5 \%, 3.0 \pm 0.4 \times 101^{2} / \mathrm{L}, 7.8 \pm 0.6 \mathrm{~g} /\right.$ dl, $21.3 \pm 3.5 \%, \quad 71.4 \pm 8.4 \mathrm{fl}, \quad 150.0 \pm 13.1 \times 10^{9} / \mathrm{L}$ ) compared to the control $\left(30.7 \pm 5.2 \%, 5.1 \pm 0.7 \mathrm{X} 101^{2} / \mathrm{L}, 13.7 \pm 1.2 \mathrm{~g} / \mathrm{l}\right)$ and no significant difference $(\mathrm{P}>0.05)$ in eosinophil, basophil and mean cell haemolgobin of the Grave's disease subjects compared to the control. ESR=Erythrocyte sedimentation rate, $\mathrm{WBC}=$ Total white cell count, RBC= Red blood cell, $\mathrm{PCV}=$ packed cell volume, $\mathrm{MCV}=$ Mean cell volume, $\mathrm{MCH}=$ Mean cell haemoglobin, $\mathrm{MCHC}=$ Mean cell haemoglobin concentration, $\mathrm{GD}=$ Graves' disease subjects (Figure 1-5) (Table 1).

Table 1:Hematological markers of Graves disease subjects and the control.

\begin{tabular}{|c|c|c|c|}
\hline Parameters & GD & Control & $\begin{array}{c}\text { Level of } \\
\text { Significance }\end{array}$ \\
\hline ESR (mm/hr) & $112.0 \pm 6.7$ & $8.9 \pm 3.2$ & $\mathrm{P}<0.05$ \\
\hline WBC (X109/L) & $17.3 \pm 2.6$ & $5.2 \pm 0.3$ & $\mathrm{P}<0.05$ \\
\hline Neutrophil (\%) & $88.8 \pm 6.2$ & $68.1 \pm 8.3$ & $\mathrm{P}<0.05$ \\
\hline $\begin{array}{c}\text { Lymphocyte } \\
\text { (\%) }\end{array}$ & $7.2 \pm 0.5$ & $30.7 \pm 5.2$ & $\mathrm{P}<0.05$ \\
\hline Monocyte (\%) & $3.7 \pm 0.3$ & $0.1 \pm 0.1$ & $\mathrm{P}<0.05$ \\
\hline Eosinphil (\%) & $0.1 \pm 0.1$ & $0.1 \pm 0.1$ & $\mathrm{P}>0.05$ \\
\hline Basophil (\%) & $0.2 \pm 0.1$ & $0.1 \pm 0.1$ & $\mathrm{P}>0.05$ \\
\hline RBC (X1012/L) & $3.0 \pm 0.4$ & $5.1 \pm 0.7$ & $\mathrm{P}<0.05$ \\
\hline $\begin{array}{c}\text { Haemoglobin } \\
\text { (g/dl) }\end{array}$ & $7.8 \pm 0.6$ & $13.7 \pm 1.2$ & $\mathrm{P}<0.05$ \\
\hline PCV (\%) & $21.3 \pm 3.5$ & $40.7 \pm 6.1$ & $\mathrm{P}<0.05$ \\
\hline MCV (fl) & $71.4 \pm 8.4$ & $79.8 \pm 9.1$ & $\mathrm{P}<0.05$ \\
\hline MCH (pg) & $26.1 \pm 2.4$ & $26.8 \pm 1.6$ & $\mathrm{P}>0.05$ \\
\hline MCHC (g/l) & $365.0 \pm 21.0$ & $336.0 \pm 15.2$ & $\mathrm{P}<0.05$ \\
\hline $\begin{array}{c}\text { Platelets } \\
\text { (X109/L) }\end{array}$ & $150.0 \pm 13.1$ & $162.0 \pm 21.6$ & $\mathrm{P}>0.05$ \\
\hline
\end{tabular}

\section{Discussion}

The results showed marked leukocytes is in the Graves' disease subjects. This shows increased synthesis and release of total white cells which may probably be linked to the stress they were undergoing. The neutrophils and erythrocyte sedimentation rate were seen significantly elevated. This could be as a result of release of toxic substances and the stress the body is undergoing. Red blood cells, haemoglobin, packed cell volume, mean cell volume, platelets and lymphocytes show significant decrease. This shows that the bone marrow may be suppressed, increased destruction of red cells and ineffective erythropoiesis. The erythrocyte sedimentation rate recorded a very high significant value which shows that the blood may be less viscous and low density because of low red cells in the circulation.

The hormonal imbalance may be the major contributory factor because of hyperthyroidism state of the body. This leads to high metabolic rate which shatters the entire system and that may be the main cause of this alterations seen in these 
hematological markers studied. Hematologic involvement is not uncommon in Graves' disease (GD) and can have a wide spectrum implication according to Ford and Carter [12]. The haematopoietic system is altered in hyperthyroidism and alterations can be seen in all three blood cell lineages [12,13]. Graves' disease is the most common cause of hyperthyroidism and results from production of auto antibodies that bind to and stimulate the TSH receptors [14]. Complications of GD occur by two main mechanisms: one is the ensuing thyrotoxic state which can affect almost every organ system in the body and second is the concurrent autoimmune process and association with other autoimmune diseases [14,15].

However, anemia can be seen in hyperthyroid patients because of simultaneous increase in plasma volume, shorter erythrocyte life span, abnormal iron utilization, or deficiency of iron, vitamin B12, or folate. Hyperthyroidism and autoimmunity contribute to the pathogenesis of pancytopenia in GD patients $[12,13]$. The clinical impact of the Graves's disease on the heamatological parameters of the victims could be massive, especially in the remote communities of the region, where this study was conducted. These could be linked to increasingly trend of lack of functional health facilities, lack of trained personal for prompt diagnosis and management of the disease, even as access to drug for treatment remains a huge challenge due to poverty. Also lack of access to health education to promote a sustainable preventive measures remained a source of concern and very visible in the region of this present study [16-18].

\section{Conclusion}

Graves's disease is associated with various hematological abnormalities as shown from this study. Thereare serious changes in all the blood cell lineages. This shows that the bone marrow may be affected. Therefore the hematological alterations seen Grave disease patients could be attributable to autoimmunity, hyperthyroidism and nutritional deficiency. Genetic factors may be involved in this disorder. Infection and stress could also contribute to the complications in Gaves disease. Haematological parameters should be seriously monitored periodically in the course of treatment of Graves' disease over time.

\section{References}

1. Menconi F, Marcocci C, Marinò M (2014) Diagnosis and classification of Graves' disease. Autoimmun Rev 13(4-5): 398-402.

2. Brent GA (2008) Clinical practice. Graves disease. N Engl J Med 358(24): 2594-2605.
3. Nikiforov YE, Biddinger PW, Nikiforova LDR, Biddinger PW (2012) Diagnostic pathology and molecular genetics of the thyroid $\left(2^{\text {nd }} e d n\right)$, Philadelphia: Wolters Kluwer Health/Lippincott Williams \& Wilkins, p. 69.

4. Agabegi ED, Agabegi SS (2008) Step-Up to Medicine (Step-Up Series). In: Hagerstwon, Lippincott Williams \& Wilkins, pp. 157.

5. Kenneth LB (2001) Principles and Practice of Endocrinology and Metabolism. ( $3^{\text {rd }} \mathrm{edn}$ ), Philadelphia: Williams \& Wilkins, pp. 636.

6. Muldowney FP, Crooks J Wayne EJ (1957) The total red cell mass in thyrotoxicos is and myxoedema. ClinSci 16(2): 309-314.

7. Das KC, Mukherjee M, Sarkar TK, Dash RJ, Rastogi GK (1975) Erythropoiesis and erythropoietinin hypo- and hyperthyroidism. J Clin Endocrinol Metab 40(2): 211-220.

8. Khojasteh A, Perry MC (1982) Thyrotoxic erythrocytosis. South Med J 75(3): 379-380

9. Rodman GP, Jensen WN (1957) A study of red blood cell survival in hypo- and hyperthyroidism. Clin Res 5: 8.

10. Mc Clellan JE, Donegan C, Thorup OA, Leavell BS (1958) Survival time of the erythrocyte in myxedema and hyperthyroidism. J Lab Clin Med 51(1): 91-96.

11. Gibson JG, Harris AW (1939) Clinical studies of the blood volume V. Hyperthyroidism and myxedema. J Clin Invest 18(1): 59-65.

12. Ford HC, and Carter JM (1988) The haematology of hyperthyroidism: abnormalities of erythrocytes, leucocytes, thrombocytes and haemostasis. Postgrad Med J 64(756): 735-742.

13. Orwoll ES, and Orwoll RL (1987) Hematologic abnormalities in patients with endocrine and metabolic disorders. Hematol Oncol Clin North Am 1(2): 261-279.

14. Franklyn JA, and Boelaert K (2012) Thyrotoxicosis. The Lancet 379(9821): 1155-1166.

15. Boelaert K, Newby PR, Simmonds MJ, Holder RL, Carr-Smith JD, et al. (2010) Prevalence and relative risk of other autoimmune diseases in subjects with autoimmune thyroid disease. The American Journal of Medicine 123(2): 183.e1-183.e9.

16. Azuonwu O, NnennaI, Uwuma OE (2017) Evaluation of Haematological Profile of Geriatric Subjects in Port Harcourt Metropolis of Niger Delta of Nigeria. J Clin Lab Med 2(1).

17. Azuonwu O, Nnenna I, Douglass AS, Ntaa NB (2016) Consequences of Haemolytic Disease of the Fetus and Newborn (HDFN) and the Clinical Significance of Antibody Screening in Prenatal Diagnosis: A Study of Multigravidal and Primigravidal Women in Port Harcourt, Niger Delta. J Clin Lab Med 1(1).

18. Azuonwu O, Nnenna Ihua, Oritsemisan S (2017) Evaluation of CoMorbidity Impact of Diabetic Disorders on Some Haematological Profile of Patients Assayed in Port Harcourt, Niger Delta, Nigeria: A Public Health Concern. Open Acc Blood Res Trans J 1(3): 5. 
This work is licensed under Creative Commons Attribution 4.0 License DOI: 10.19080/OABTJ.2017.01.555568

\section{Your next submission with Juniper Publishers will reach you the below assets}

- Quality Editorial service

- Swift Peer Review

- Reprints availability

- E-prints Service

- Manuscript Podcast for convenient understanding

- Global attainment for your research

- Manuscript accessibility in different formats

( Pdf, E-pub, Full Text, Audio)

- Unceasing customer service

Track the below URL for one-step submission https://juniperpublishers.com/online-submission.php 